\title{
Systematic Persecution of Religious Minorities: Bangladesh Perspective
}

\author{
Md. Rajib Hasnat Shakil ${ }^{1}$
}

\begin{abstract}
Minority people are facing challenges in Bangladesh for decades on the impacts of State's denial of rights to a section of people in the country. Rulers always use law to realize their dishonest intention. Bangladesh got such experience for several times. When State appears to be the best patron to the process of discrimination, injustice and violation, the targeted communities are deprived of their economic, political and cultural existence. In Bangladesh, because of the prevailing 'Constitutional equality and moderate Muslim democracy' propaganda, the agonies of vanishing minorities go unknown and unheard to international communities. Denying people's rights equality and democracy becomes meaningless, which ultimately benefits none. For a sustainable development State must embrace all including minorities, with due honor and respect.
\end{abstract}

Keywords: Group, persecution, religious minority, violation, vanishing minority.

\section{Introduction}

Despite the country ceasing to be a secular state constitutionally, secularism has been practiced in the region of Bengal since ancient times. In fact, secularism in the region as a whole is in many ways different from that of Western versions that assert complete separation of church and state. The ethos of secularism in South Asia is fundamentally the freedom of individuals to practice the faith he or she desires without being subject to any form of state or communal discrimination in literally. But practically in Bangladesh the government publicly supported freedom of religion; however, attacks and discrimination against religious and ethnic minorities continued during the reporting period. In general, government institutions and the courts protected religious freedom. Religious minorities are often at the bottom of the social hierarchy and, therefore, have the least political recourse. Hindu, Christian, and Buddhist minorities experienced discrimination and sometimes violence from the Muslim majority. Harassment of Ahmadis also occurred. It is sad to note that some religious minorities, in particular Ahmadiyya and Hindus, have become victims of violence of certain element of fanatic forces within the country. In my view, Islam totally rejects such violence. It seems to be a serious misunderstanding and misinterpretation of Islam ${ }^{2}$.

\section{Religion and Politics: Bangladesh Perspective}

Bangladesh rests on a set of primordial socio-cultural, linguistic and religious identities that have been distinctively shaped by the history of the Bengal delta. The socio-economic system around which modern civilization has grown up in Bengal is derived from a distinctive cultural-religious ideology. As a result, relatively flexible religious ideologies were mobilized around the mode of production and economic life of the people ${ }^{3}$.

Subsequent attempts to construct a unique linguistic or religious identity within Bangladesh have tended to ignore the multiple identities around issues of language, class and profession, and this has occasionally served to provoke confrontation and violence.

\begin{tabular}{|c|c|c|c|c|c|}
\hline \multicolumn{2}{|c|}{ Hindu Population across Banglades $h^{4}$} & \multicolumn{4}{|c|}{ Population of Bangladesh $^{5}$} \\
\hline \multirow{5}{*}{$\begin{array}{l}\text { District } \\
\text { Barisal } \\
\text { Chittagong } \\
\text { Dhaka }\end{array}$} & \multirow{5}{*}{ Percentage (\%) } & $\begin{array}{l}\text { Religious } \\
\text { group }\end{array}$ & $\begin{array}{l}\text { Population } \\
\% 1975\end{array}$ & $\begin{array}{l}\text { Population } \\
\% 1990\end{array}$ & $\begin{array}{l}\text { Population } \\
\% 2010\end{array}$ \\
\hline & & Muslim & $84 \%$ & $87 \%$ & $89.5 \%$ \\
\hline & & Hindu & $15.6 \%$ & $12.4 \%$ & $9.5 \%$ \\
\hline & & Christian & $0.1 \%$ & $0.1 \%$ & $0.3 \%$ \\
\hline & & Buddhist & $0.3 \%$ & $0.5 \%$ & $0.7 \%$ \\
\hline
\end{tabular}

\footnotetext{
${ }^{1}$ Senior Lecturer, Department of Law, Northern University Bangladesh

${ }^{2} \mathrm{http}: / /$ www.thedailystar.net/law/2004/10/01/

${ }^{3}$ Kaniz Marzia, BSS, MSS (University of Dhaka, Bangladesh)

${ }^{4}$ Census Report of Bangladesh

${ }^{5} \mathrm{Ibid}$
} 


\begin{tabular}{|ll|l|}
\hline $\begin{array}{l}\text { Khulna } 16.45 \\
\text { Rajshahi } 12.09\end{array}$ \\
Sylhet 17.80 & \\
\hline \multicolumn{2}{|c|}{ Hindu Population across Bangladesh(Administration) } \\
\hline \multicolumn{1}{|c|}{ District } & Percentage (\%) \\
\hline Barisal & 11.70 \\
\hline Chittagong & 12.65 \\
\hline Dhaka & 10.5 \\
\hline Khulna & 16.45 \\
\hline Rajshahi & 12.09 \\
\hline Sylhet & 17.80 \\
\hline
\end{tabular}

\section{Definition of Minority}

Sociologist Louis Wirth defined a minority group as "a group of people who, because of their physical or cultural characteristics, are singled out from the others in the society in which they live for differential and unequal treatment and who therefore regard themselves as objects of collective discrimination ${ }^{7} . " G e n e r a l l y$, the minority is thought of as the opposite of the majority. In democratic societies, it is based on the numerical ratio to the population as a whole in a particular place. But in international law the term "minority" is commonly used in more restricted sense. It has come to refer to a particular kind of group, which differs from the dominant group within the state.

\section{Features of Minorities}

A minority group is an inferior social group. Its member's endure disadvantages consequential from prejudice and inequity. These may include separation and singling out.

$>$ Having own physic, culture, dialect etc the members of a minority group treats as in low esteem by dominant group. The group usually has distinguished characteristics.

$>$ There are existing group feelings of loyalty .They identify themselves different, as part of a group.

$>$ Traditionally it follows or grows by birth but not voluntary that means birth of a child from a group treats a group member.

> Memberships of a minority group have strong bounds of brotherhood and generally believe in endogamy.

$>$ They have tendency to preserve their language, culture, solidarity etc. They usually want to practice it. It matters that lower tendency is group faces extinction and higher tendency a group can be sustained in longer time.

\section{Minorities in Bangladesh}

Bangladesh belongs to a multi-ethnic, multi-religious and multi-lingual pluralistic society. Its people have variety of beliefs. Several languages are spoken in different parts of the country, especially in the tribal areas. And a good number of ethnic groups live in the north and northeastern part of the country. Beside this, a good number of Biharis (stranded Pakistanis) are also residing in different parts of Bangladesh. Therefore, the minorities in Bangladesh can be classified under four different heads ${ }^{8}$ :

$>$ Religious Minorities;

Ethnic Minorities;

$>$ Linguistic Minorities; and

$>$ Other minorities

\section{Religious Minority}

A group whose religious obligations result in patterns of behavior among its members that result in discriminatory treatment by the mainstream society. Persons belonging to religious minorities have a faith which is different from that held by the majority. Most countries of the world have religious minorities. However in many countries this freedom is constricted. For example in Egypt, a new system of identity cards. "The Situation of the Bahari Community of Egypt" and "Religion Today: Bahais' struggle for recognition reveals a less tolerant face of Egypt",)

Four Patterns:

\footnotetext{
${ }^{6}$ supra

${ }^{7}$ Barzilai, G. Communities and Law: Politics and Cultures of Legal Identities.. Ann Arbor: University of Michigan Press., Wirth, L: "The

Problem of Minority Groups.", page 347 in Ralph Linton (ed.), Columbia University Press 1945.

${ }^{8}$ Gobinda Chandra, Mandal Rights of Minorities: The Case of Bangladesh, Dept of law, University of Dhaka
} 
1) Full Social Assimilation of the religious minority

2) Minority Group Extinction as a result of

3) Minority Group Isolation without assimilation

4) Partial Assimilation of the religious minority

VII. Minority Rights in Bangladesh

Religious pluralism is a golden thread running through the Constitution that was adopted on November 4, 1972 .

Rights guaranteed by Constitution ${ }^{10}$
The concept of freedom of religion is further
stipulated in Article 41 of the Constitution, which
is as follows:
"(1) Subject to law, public order and morality:
(a) Every citizen has the right to profess, practice
or propagate any religion;
(b) Every religious community or denomination
has the right to establish, maintain, and manage
its religious institutions

(2) No person attending any educational institution shall be required to receive religious instruction, or to take part in or to attend any religious ceremony or worship, if that instruction, ceremony or worship relates to a religion other than this own."Article 41 is founded upon on religious pluralism. In Bangladesh, people of various faiths are deeply religious, and the most devoutly religious people are also the staunchest defenders of religious pluralism.

\begin{abstract}
Rights by International Mechanism
The United Nation's concept and protection of minorities came to be incorporated in its Covenant on Civil and Political Rights. Article 27 of the Covenant is specifically concerned with the situation of persons belonging to the minorities ${ }^{11}$ :On the basis of a logical and literal interpretation of the Article, the following certain positive rights have been conferred on the members of the minority groups:

I. to enjoy their own culture,

II. to profess and practice their own religion, or

III. to use their own language

In Article 18(2) of the Covenant The 1966 UN International Covenant on Civil and Political, it provides that "No one shall be subject to coercion which would impair his freedom to have or to adopt a religion or belief of his choice"

"respect and ensure all individuals within its territory" (Article 2 of the Covenant)..

"Religion or belief, for anyone who professes either, is one of the fundamental elements in his conception of life and that freedom of religion or belief should be fully respected and guaranteed."(CEDAW ${ }^{12}$ )

In Article 2(2) of the UN Declaration it provides that "No one shall be subject to coercion which would impair his freedom to have a religion or belief of his choice."
\end{abstract}

\section{The present nature of persecution on the minorities}

The present nature of persecution on the minorities may be described as follows:

1. Grabbing of individual minority properties by interested individual or groups by force and threat.

2. Eviction of large scale poor minority families living in a village, over a Khash lands living there from generation to generation, some times in the name of development.

3. Eviction of Adibashis from their ancestral lands or forests in the name of making 'Avayaranya' (place of sanctuary), tourist resorts, place of holidaying.

4. Rape and sexual violation of women belonging to minority communities. Ill treatment meted with young tribal girls and women

5. Constant threat to minority communities

6. Places of worships are violated and sanctity of the temples, churches, mosques of Ahmeddiya

\section{Violation to Religious Rights}

In 2002, 147attacks on Hindu religious institutions have been reported in the media. In several parts of the country, house deities, temples were destroyed, festivals were disrupted and debutter property seized ${ }^{13}$.

\footnotetext{
${ }^{9}$ Wednesday, July 20, 2011.Daily Star

${ }^{10}$ The Constitution of the Peoples' Republic of Bangladesh

${ }^{11}$ Covenant of Economic, Social and Cultural Rights, 1966

${ }^{12}$ Convention on the Elimination of All Forms of Discrimination Against Women

${ }^{13}$ (36 Amena Mohsin, Rights of Minorities in Bangladesh, in Human Rights in Bangladesh-2002, Ain O Salish Kendra, Dhaka2003, P.229230)
} 


\section{X. $\quad$ Loss of Land Rights}

Religious minorities outside the $\mathrm{CHT}^{14}$ have also been displaced as a result of discrimination or communal violence. The Hindu community in particular lost much of its land due to the nationalist Vested Property Act of 1974. This act was repealed in 2001, but there has since been no restitution of land to minorities. Communal violence, particularly between 2001 and 2006 when the Bangladesh Nationalist Party was in power, is believed to have affected many religious minorities including the Ahmadi Islamic sect. Elections in December 2008 brought a new government to power and its premier has promised a full implementation of the 1997 peace accord in the CHT and protection of religious minorities all over the country. The government must implement these pledges if the situation of internally displaced people is to improve.

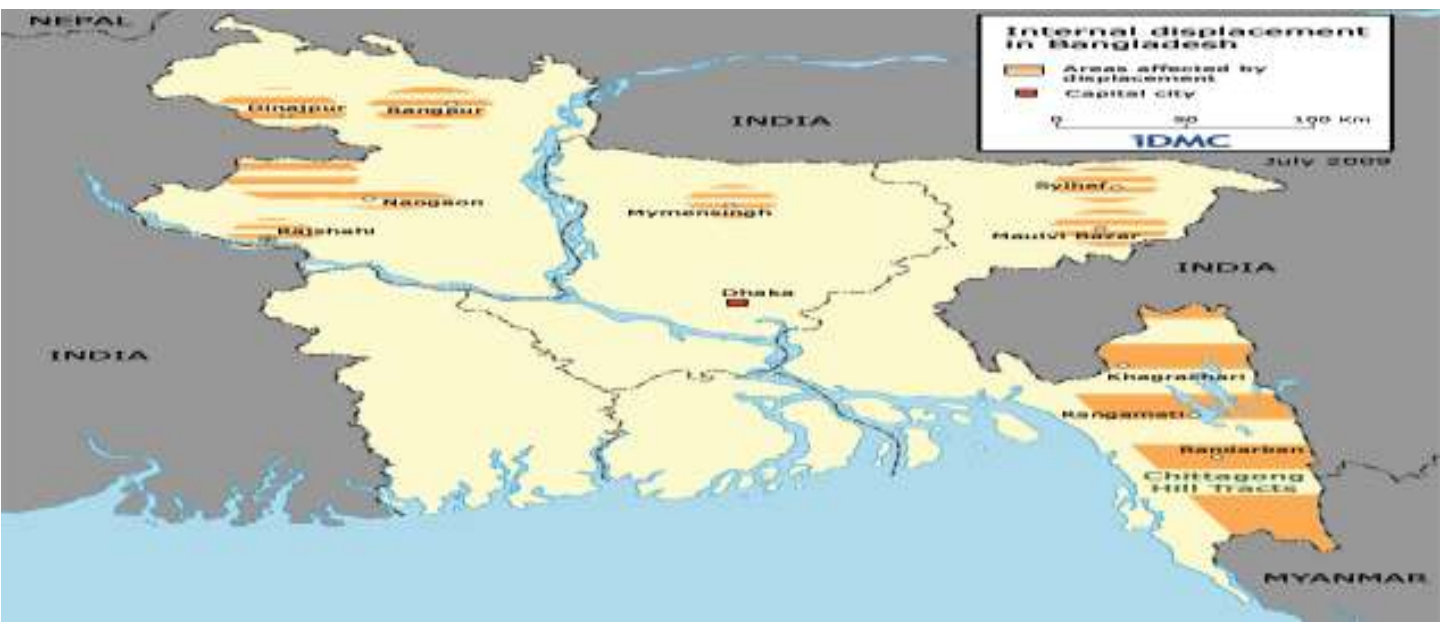

Source: $\underline{w w w . i n t e r n a l-d i s p l a c e m e n t . o r g ~}$

In 2002, 56 cases of land grabbing has been reported in the media. Santhals, Khasias and Rakhains have been the victims of land grabbing, often at the behest of influential, political leaders both in position and opposition ${ }^{15}$.

\section{Violence against Women}

"When the overall religious minorities in Bangladesh are considered as 'Infidel', it is easily understandable that the condition of the minority women, who are first infidel and then women, a double crime and they have to pay double the price. So the rate of rape of minority women is much higher in Bangladesh ${ }^{16}$."Watch World Report says that: "...Attacks against Hindus in Bangladesh escalated dramatically...Scores of Hindu women and girls were raped. In some cases, they were gang raped in front of their male relatives. Hindus were also assaulted on the streets, in their homes, and at their workplaces. The government did little to prosecute or investigate the fact ${ }^{17}$,

The patriarchal values of the society strengthen the hands of the dominant community and they find it easy to transgress the rights of the minority communities; at the same time patriarchy within the minorities make women even more vulnerable and marginalized. Cases of rape, acid throwing, harassment, torture and other brutal forms of violence are reported in the newspapers. The brutality of the violence may be assumed from the facts of the cases. Mother is being raped in front of he children; wife before the husband and sometimes mother and daughter are becoming the victims of gang rape.

\section{Torture and Extortion}

Extortion has become a norm in the political and social fabric. The minorities are more vulnerable because of their vulnerability. Their refusal to meet unjust extortion demands exposes them to violence or threats. It is important to note that threats to leave the country are not made to the members of the majority

\footnotetext{
${ }^{14}$ Chittagong Hill Tracts, Bangladesh

15 (36 Amena Mohsin, Rights of Minorities in Bangladesh, in Human Rights in Bangladesh-2002, Ain O Salish Kendra, Dhaka2003, P.229230)

${ }^{16}$ Asian Tribune, Vol. 11 No. 395

${ }^{17}$ Human Watch World Report 2003
} 
community. This suggests that the process of creating otherness amongst minorities has seeped into the sinews of the state and society.

\section{Attacks on Life and Property}

Attacks against the Hindu community continued, although numbers dropped significantly from the previous year. Hindu places of worship have been ransacked, villages destroyed and scores of Hindu women are reported to have been raped and injured. According to the Bangladesh Buddhist-Hindu-Christian Unity Council (BHBCOP), during the period from March 2009 to May 2010 there were at least 150 incidents of repression including land seizures, arson, rape, and at least three killings. Most of the land seizures took place in the districts of Natore, Pirojpur, Chittagong, Narsingdi, Bagerhat, Bariasl, Manikganj, Tangail, Satkhira, Pabna, Manikganj, and Munshiganj ${ }^{18}$.

\begin{tabular}{|c|c|}
\hline Published In & Events \\
\hline Times of India, on February 5, 2010, & $\begin{array}{l}\text { A group of } 30 \text { to } 35 \text { men attacked an ancient Hindu } \\
\text { temple in Sonargaon of Narayanganj District. The } \\
\text { group vandalized the temple and four houses, injuring } \\
\text { at least five persons and destroying six idols. The } \\
\text { attack followed an altercation between a devotee and } \\
\text { three youths from the village. }\end{array}$ \\
\hline $\begin{array}{l}\text { According to the New Age, a daily English } \\
\text { newspaper, between March and May } 2010\end{array}$ & $\begin{array}{l}\text { Individual allegedly attempting to seize land felled } \\
\text { forty trees belonging to the Hindu community and } \\
\text { occupied the Arpara Bazar Temple land in the Sadar } \\
\text { upazila. }\end{array}$ \\
\hline $\begin{array}{l}\text { According to Naya Diganta, a daily Bengali } \\
\text { newspaper, on April 20, } 2010\end{array}$ & $\begin{array}{l}\text { A group of individuals attempting to seize land, } \\
\text { backed by the local Chhatra League, the student wing } \\
\text { of the Awami League party, occupied the Shree Shree } \\
\text { Rajeshwari Temple in the village of Ambaria. The } \\
\text { temple property was still in dispute, and the local } \\
\text { Hindu community was unable to worship there. }\end{array}$ \\
\hline $\begin{array}{l}\text { According to the Daily Amar Desh of 21st } \\
\text { of May, } 2010\end{array}$ & $\begin{array}{l}\text { Powerful perpetrators grabbed cremation grounds and } \\
\text { lands belonging to the Hindu Minority at Zia Nagar in } \\
\text { Perojpur District. In addition, many Hindus have been } \\
\text { unable to recover landholdings lost because of } \\
\text { discrimination under the Vested Property Act. The } \\
\text { Bangladesh Cabinet has approved the Vested Property } \\
\text { Return (Amendment) Act } 2009 \text { for restoring property } \\
\text { seized from minority groups, } \\
\text { mainly from Hindus, during the united Pakistan era.5 } \\
\text { Leaders of different organizations }\end{array}$ \\
\hline The Hindu, 3 November 2009 & $\begin{array}{l}\text { Bangladesh Cabinet approves law to return vested } \\
\text { property to minorities. }\end{array}$ \\
\hline Ramu Violance On 29 September 1012 & $\begin{array}{l}\text { On } 29 \text { September, at around } 10 \text { P.M. at night, some } \\
\text { people staged a procession in Ramu in protest of the } \\
\text { perceived blasphemous image uploaded to a Facebook } \\
\text { account. Newspaper reports claimed that local Awami } \\
\text { League leaders were initially seen mobilizing the mob } \\
\text { emphasizing the sentimental religious issue to edge out } \\
\text { the opposition. The Daily Star }{ }^{19} \text {, a widely circulated } \\
\text { national daily at Bangladesh, reported that a motley } \\
\text { group comprising local leaders of pro-Awami League } \\
\text { organizations, BNP men, madrasa students and }\end{array}$ \\
\hline
\end{tabular}

\footnotetext{
${ }^{18}$ Asian Tribune, Vol. 11 No. 395

${ }^{19}$ The Daily Star
} 


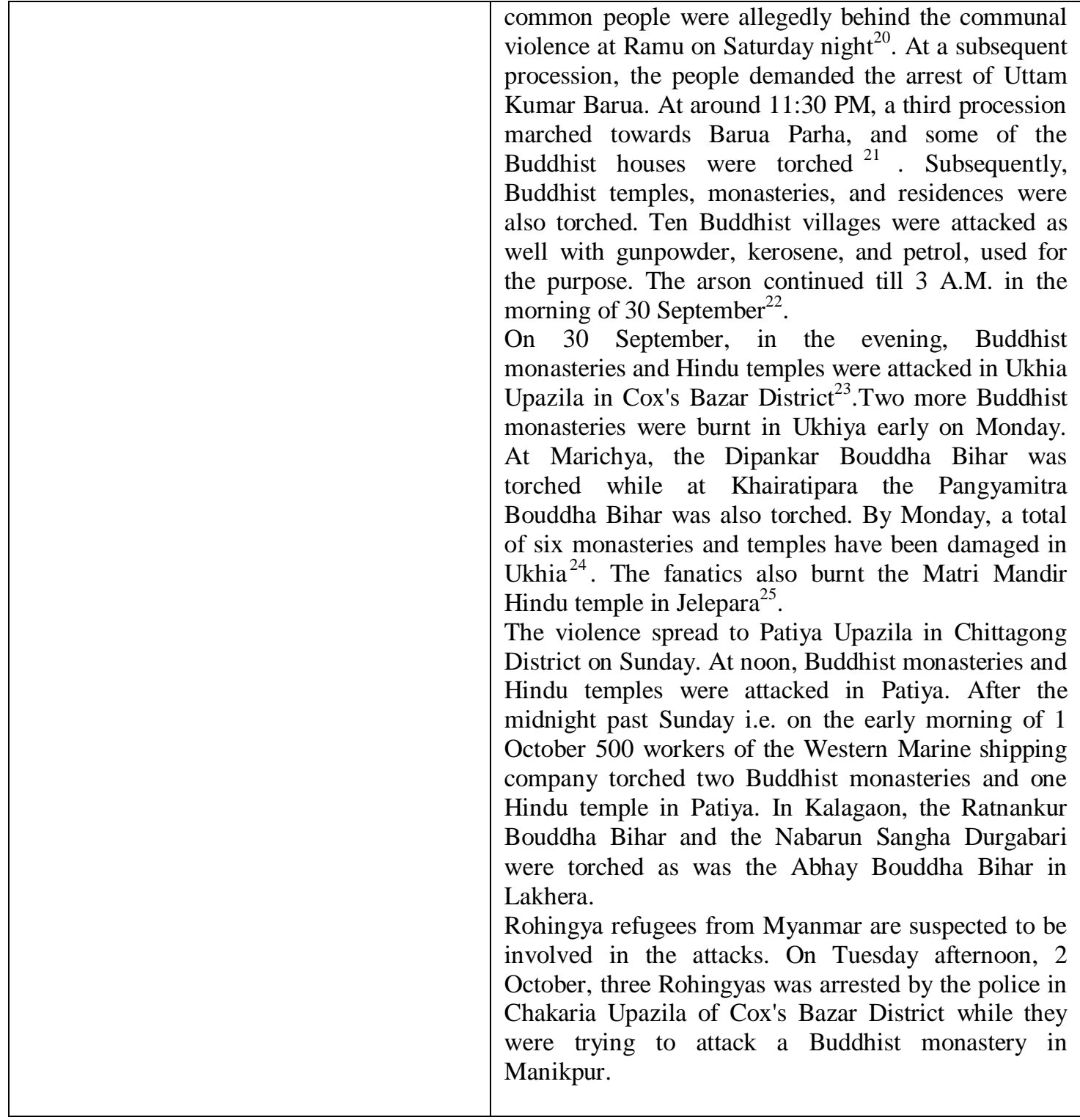

\section{Abduction and Forcible Eviction}

Nine cases of abduction and fifty-four cases of forcible evictions of minority communities from their land and homestead have been reported in 2002. In some cases the evictions are caused in a mass scale. In March 2002, in Durgapur about 20 villages inhabited by minorities came under attack and about 500 inmates of those villages were evicted from their homes. In the same month, 32 families had to flee their village in Daganbhuiyan $^{26}$.

\section{XV. $\quad$ Forceful Conversion to Islam}

Though once it was very common, but not rare even these days. It happens now and then everywhere in different ways. Minority girls become the main targets. In most of the cases the perpetrators causes it applying

\footnotetext{
${ }^{20}$ Inam Ahmed, Julfikar Ali Manik (3 Oct 2012). "A hazy picture appears". The Daily Star. Retrieved 24 Oct 2012.

21 "Buddhist temples, homes burned, looted in Ramu". Bangladesh News 24. 30 Sep 2012. Retrieved 3 Oct 2012

22 "Ramu Violence: Home Minister points finger at MP". BDNEWS. 30 Sep 2012. Retrieved 3 Oct 2012.

23 "166 nabbed for Ramu rampage". Daily Sun. 2 Oct 2012. Retrieved 2 Oct 2012.

${ }^{24}$ Juberee, Abdullah; Atikuzzaman, A.K.M. (2 Oct 2012). "Mobs torch two more monasteries in Cox's Bazar". New Age. Retrieved 2 Oct 2012

25 "24 Buddhist and Hindu temples burnt in Bangladesh - India and UN urged to intervene" (Press release). Asian Centre for Human Rights. 1 Oct 2012. Retrieved 4 Oct 2012.

${ }^{26}$ Amena Mohsin, Rights of Minorities in Bangladesh, in Human Rights in Bangladesh-2002, Ain O Salish Kendra, Dhaka2003, P.229-230
} 
force, fear and inducement. In some cases, the minority girls are kidnapped, with the active support of the local mastans. Local administration and politicians and religious leaders play important roles to make that.

\section{Vanishing Minority Population}

The Internal Displacement Monitoring Centre highlights the significant rise in Hindus escaping to India as a result of the "increasing communalization of politics in Bangladesh". However, the IDMC observes that this is not a first option for many Hindus in Bangladesh who simply accept internal displacement as a "way of coping with contemporary political realities ${ }^{27,}$

\begin{tabular}{ccc}
$\begin{array}{c}\text { Declining } \\
\text { Year }\end{array}$ & \multicolumn{2}{c}{$\begin{array}{c}\text { Hindu population in Bangladesh region } \\
\text { Percentage }(\boldsymbol{\%})\end{array}$} \\
$\mathbf{1 9 4 1}$ & 28.0 & \\
$\mathbf{1 9 5 1}$ & 22.0 \\
$\mathbf{1 9 6 1}$ & 18.5 \\
$\mathbf{1 9 7 4}$ & 13.5 \\
$\mathbf{1 9 8 1}$ & 12.13 \\
$\mathbf{1 9 9 1}$ & 11.62 \\
$\mathbf{2 0 0 1}$ & 9.2 &
\end{tabular}

Source: Census of India 1941, Census of East Pakistan, Bangladesh Government Census

\section{Attacks on Ahmadiyas}

Attacks on institutions of the Ahmadiya Muslim Community and isolated instances of harassment were reported. There are approximately 100,000 Ahmadis concentrated in Dhaka and several other locales. A series of attacks between June 17 and August 8, 2010, left 20 members of the Ahmadi community in the Ghatail upazila injured and severely damaged homes and religious institutions. Ahmadi community leaders reported the attacks to the police, but there were no arrests ${ }^{28}$.

\section{How are religious minorities, notably Hindus, treated in Bangladesh?}

In general, minorities in Bangladesh have been consistently mistreated by the government and Islamist extremists. Specific discrimination against the Hindu minority intensified immediately following the 2001 national elections when the Bangladesh Nationalist Party (BNP) gained victory with its four-party coalition government, including two Islamic parties. According to several sources, attacks against Hindus continue to occur. Similar atrocities against the Hindu minorities were also reported throughout 2006 ('Election time in Bangladesh: Minorities face risks of more rights violations' 2006, Asian Centre for Human Rights (ACHR)

Other Violence ${ }^{29}$ :

$\begin{array}{ll}\text { Name of violence } & \text { Number of affected } \\ \text { Torture } & 8 \\ \text { Suicide } & 1 \\ \text { Rape } & 111 \\ \text { Gang Rape } & 44 \\ \text { Rape followed Murder } & 14\end{array}$

Human rights violation at Hill Tracks ${ }^{30}$ :

$\begin{array}{ll}\text { Incident } & \text { Number of occurrences } \\ \text { Murdered } & 18 \\ \text { Kidnapped } & 17 \\ \text { Injured } & 63 \\ \text { Arrested } & 36\end{array}$

\footnotetext{
${ }^{27}$ Norwegian Refugee Council 2005, 'Profile of Internal Displacement: Bangladesh', Global IDP Project website, 25 February, p.15

${ }^{28}$ Amena Mohsin, Rights of Minorities in Bangladesh, in Human Rights in Bangladesh-2002, Ain O Salish Kendra, Dhaka2003, P.229-230

${ }^{29}$ Source: Right, Prep Trust and News papers.

${ }^{30}$ supra
} 
Overwhelming $98.68 \%$ of the rape victims are minority, and rapists happen to be the cadres of the ruling parties. (The Daily Jankantha, Feb. 17, 2002). Nearly "200 Hindu women were gang raped" in Char Fashion, Bhola, in one night at a single spot. (The Daily Star, Nov. 16, 2001). The police do not allow the minorities to press charges against the rapists, and if they insist they are given a run around for a few days so the evidence of rape disappear, and then the police officers themselves persecute them. On 10 December 2001, The Washington Times published an article describing the influx of Awami League supporters to India, "the great majority of them Hindus who complain of murder, rape and looting at the hands of fundamentalist backing the newly elected party" (Rahman. S.A. 2001, 'Indian parties plead Hindu refugees' cause', The Washington Times, 10 December). On 24 October 2001, The Hindu states that "supporters of the Awami League and Hindus, considered the party's vote-bank, are being subjected to persecution in Bangladesh, consequent to the elections" ('Hindu families fleeing Bangladesh' 2001, The Hindu, 24 October - Attachment 8). On 22 October 2001, The Hindu reported that "Hindus were targeted on the charge of supporting a particular political concept" ('Hindus fleeing Bangladesh' 2001, The Hindu, 22 October). The same types of violence have been repeatedly taking places during the transition periods of government.

\section{Tensions that boiled over into violence}

On 10th February 2012, the Tensions that boiled over into violence originated on 9th February morning, following rumors that a mosque had been attacked. Allegations have it that houses of Hindus in the area were also attacked, according to the media reports on 10th February 2012, morning, temples in the area were vandalized and shops owned by Hindus were torched and looted after local students in the area gathered following an announcement through a PA system, according to the media reports. Finally local police clamped Section $144^{31}$ banning public gathering at Hathazari amid mounting tensions after several Hindu temples were vandalized and torched.

\section{Searching Safe Place for Religious Minority}

There exists no definitive information to state that someone who is Hindu would be safer in one area or another. Many Hindus fled to India after the coalition took power in 2001 in order to escape attacks by sections of the majority. One report by The South Asian states that "at least 10,000 people of the minority community from Barisal District had left their homes following attacks by activists of the fundamentalist religious party and had taken shelter in neighboring Gopalganj District, the electorate of the former Prime Minister. Many others fled to the Indian states of Tripura and West Bengal" ("Bangla Hindu Influx into Northeast India; Dhaka's disclaimer and New Delhi's tacit approval' 2003, The South Asian, and 23 December).

\section{Consequences of Such Persecution Religious Minorities}

Violence directed against religious minority communities continues to result in the loss of lives and property, but the motives--religious animosity, criminal intent, or property disputes--are often unclear. Religious minorities are vulnerable due to their relatively limited influence with political elites. Like many citizens, they are often reluctant to seek recourse from a corrupt and ineffective criminal justice system. Police are often ineffective in upholding law and order and are sometimes slow to assist religious minorities. This promotes an atmosphere of impunity for acts of violence against them. religion becomes a modus operandi to gain political interest then the true sense of democracy turns into a mere rhetoric or more or less goes back into the primordial concept of 'Papacy' or 'Papal Authority' as propounded by Plato's nationhood under the 'Philosopher King'.

\section{Recommendations}

1. Ensure fair and neutral justice to the Minorities from the Judiciary and Administrative Authority.

2. Completely Repeal the Vested (Enemy) Property Act and put into practice it immediately.

3. Implement the Peace Treaty between Bangladesh and the Chittagong Hill Tracts.

4. Renovate Secularism in the meaning of tolerance in the Bangladesh Constitution ${ }^{32}$ and the laws of the lands. Guarantee that the laws of the land and those of a free autonomous society are enforced.

5. Make available reparation to the minority sufferers including women and children of all aggression, including those of 2001 and recover them fairly and equitably.

6. Reconstruct all damaged temples and places of worship that were subject matter of violence and loathing, and bring to an end any prospect attacks on places of worships irrespective of trust and religion.

7. Prevent inequity against religious and ethnic minorities and indigenous people of Bangladesh in all levels of government and non-government jobs, including the armed military and law enforcement department.

\footnotetext{
${ }^{31}$ Bangladesh Code of Criminal procedure 1898

${ }^{32}$ Constitution of the Peoples Republic of Bangladesh
} 
8. Make sure just share of positions for the ethno-religious minorities in the military, overseas service, paramilitary, police and civil services.

9. Guarantee security of life and property of the minority communities in Bangladesh. And uphold basic human rights of all citizens enshrined in the Constitution of Peoples' Republic of Bangladesh and Universal Declaration of Human Rights.

10. Permit NGO and rights advocacy organizations to work freely in the courts. And Stop land grabbing and forced eviction of Minorities of Bangladesh.

\section{Conclusion}

To practice religion in peaceful environment is considered to be one of the fundamental elements of life of human beings. Human beings do not live only for material necessities. There is a strong need for spiritual nourishment for every human being. The respect for freedom of religion is the foundation of justice, peace and freedom in civilized society. This right is an inalienable right and cannot be derogated or diminished under any circumstances. Therefore, the non-derogable right of freedom of religion must be considered as one of those rights that must be guaranteed to all persons within a State, including in Bangladesh. Religious minorities are vulnerable to discrimination and violence due to their limited police influence and as a result of the corrupt and ineffective criminal justice system ${ }^{33}$.

\footnotetext{
${ }^{33}$ US Department of State 2009, International Religious Freedom Report for 2009 - Bangladesh, October.
} 